\title{
PENGEMBANGAN CBEEM (COMPUTER BASED EVALUATION ESSAY MODEL)
}

\author{
Donald Samuel Slamet Santosa ${ }^{1}$, Mia Galina ${ }^{2}$, Neilany Edwina Nulampau ${ }^{3}$ \\ ${ }^{1,2,3}$ President University \\ ${ }^{1}$ dsamuel@president.ac.id, ${ }^{2}$ miagalina@president.ac.id, ${ }^{3}$ neilany.edwina@president.ac.id
}

\begin{abstract}
Abstrak: Tujuan dari penelitian ini adalah untuk mengembangkan perangkat evaluasi tes uraian berbasis komputer yang diberi nama Computer Based Evaluation Essay Model (CBEEM). Penelitian ini adalah penelitian Research and Development $(R \& D)$. Penelitian menggunakan model pengembangan dari Plomp (2013). Penelitian terdiri dari 3 tahap utama, yaitu tahap penelitian, tahap pengembangan, dan tahap evaluasi. Data pada penelitian berupa data kualitatif yang dikumpulkan dengan observasi dan wawancara kepada 10 orang guru, divalidasi dengan triangulasi sumber, dan dianalisis dengan teknik Miles and Hubberman. Sedangkan tahap evaluasi model dilakukan dengan validasi ahli dan validasi praktisi yang dilakukan melalui pengisian angket validasi model yang diukur dalam skala likert dan isian secara kualitatif. Hasil penelitian menunjukkan bahwa CBEEM dapat berfungsi dengan baik, dan tervalidasi dengan baik oleh ahli dan praktisi. Langkah kerja utama dari CBEEM dimulai dengan input soal uraian dan kata kunci jawaban oleh guru, dilanjutkan dengan pengerjaan soal oleh siswa, dan akhirnya CBEEM akan mengoreksi jawaban soal uraian siswa dengan menggunakan kata kunci yang telah diinput oleh guru. Berdasarkan hasil penelitian ini, disarankan bagi guru untuk menggunakan perangkat ini apabila menghendaki kemudahan dalam koreksi soal uraian.
\end{abstract}

Kata Kunci: Computer Based Evaluation Essay Model

Abstract: The aim of this research is develop essay test evaluation software that namely Computer Based Evaluation Essay Model (CBEEM). This is Research and Development. This research use Plomp (2013) development model. This research consists of 3 main steps: research step, development step, and evaluation step. The data of this research is qualitative data that collected by observation to 10 teachers that validated by sources triangulation then analyzed by Miles and Hubberman qualitative analysis technique. In the evaluation step, the model validated by expert and practitioner by filling the validation questionnaire that measured by likert scale and also qualitative opinion. The result of this research show that CBEEM may be run well and validated by expert and practitioner. The main working step of CBEEM start by inputting questions and key words of answer by the teacher, then following by answering the questions by the students, and then CBEEM will check the answer using the keywords from the teacher. Based on the result, the teachers recommend to use this software if want to get help to check the essay test answer.

Key Words: Computer Based Evaluation Essay Model

\section{PENDAHULUAN}

Pembelajaran sebagai sebuah sistem terdiri dari kegiatan perencanaan, pelaksanaan dan evaluasi. Perencanaan yang baik apabila dilaksanakan dengan baik berpeluang besar untuk memberikan hasil belajar yang juga baik. Baiknya hasil belajar diperoleh dari pelaksanaan evaluasi terhadap tagihan-tagihan guru terhadap siswa. Tagihan tersebut dapat berupa tes, tugas, maupun hal-hal lain yang dapat ditetapkan oleh guru atau disepakati sejak awal. Meski demikian, sering kali hasil evaluasi yang diperoleh tidak sesuai harapan. Hal ini disebabkan oleh banyak faktor yang bersumber dari siswa, guru, maupun instrumen evaluasi itu sendiri. Baiknya perencanaan dan pelaksanaan tanpa didukung dengan baiknya evaluasi berdampak pada kegagalan proses pembelajaran. Untuk itulah evaluasi menjadi faktor yang sangat strategis. Stufflebeam dan Coryn (2014) mendefinisikan evaluasi sebagai sutu proses melukiskan, memeroleh, dan menyediakan informasi yang berguna untuk menilai alternatifalternatif pengambilan keputusan. Berdasarkan pengertian tersebut, tampak bahwa kegiatan awal dari evaluasi adalah mengumpulkan informasi mengenai hal yang dievaluasi. Dalam kaitannya dengan pembelajaran, maka informasi yang dimaksud adalah ketercapaian tujuan pembelajaran, yang dalam kurikulum saat ini, tujuan tersebut terjabar dalam kompetensikompetensi yang harus dikuasai oleh peserta didik.

Terdapat berbagai bentuk evaluasi yang dapat digunakan oleh guru untuk mengevaluasi 
pembelajaran. Bentuk-bentuk tersebut terdiri dari teknik tes dan nontes. Selanjutnya, evaluasi yang berbentuk tes dapat berupa tes pilihan ganda, isian singkat, menjodohkan, dan uraian. Tes yang berupa uraian memiliki keunggulan, yang salah satunya adalah kemampuan untuk mengevaluasi kemampuan pada level high order thinking.

Meski memiliki berbagai keunggulan, tes uraian memuat berbagai kelemahan yang menjadi konsekuensi logis baik bagi siswa maupun bagi guru. Sulitnya proses koreksi menjadi tantangan bagi guru apabila memilih menggunakan jenis tes uraian. Proses koreksi akan memuat berbagai kemungkinan kesalahan yang terdiri dari hal-hal berikut (Rukajat, 2018).

1. Halo effect yaitu kelemahan yang akan timbul jika dalam pencatatan observasi terpikat oleh kesan-kesan umum yang baik atau buruk pada peserta didik. Sebagai contoh apabila guru mengoreksi pekerjaan siswa yang pandai di kelas, guru akan langsung memberi nilai baik tanpa mengoreksi lebih lanjut pekerjaannya.

2. Generosity effect yaitu keinginan untuk berbuat baik atau keinginan membantu siswa. Jika guru ragu-ragu dalam memberi nilai, maka guru cenderung memberi nilai baik dengan alasan kemanusiaan.

3. Carry over effect yaitu kelemahan akibat guru tidak dapat memisahkan satu fenomena dengan fenomena lain.

4. Order effect yaitu kelemahan akibat urutan koreksi. Sebagai contoh jika guru telah menyelesaikan pekerjaan yang sangat jelek, dan pekerjaan berikutnya lebih baik, guru akan berpikir bahwa pekerjaan tersebut jauh lebih baik dari sebelumnya.

5. Kelelahan dalam koreksi.

6. Buruknya tulisan siswa (jika jawaban ditulis menggunakan pena).

Berbagai masalah yang disebutkan tersebut membuat koreksi menjadi terhambat, dan hasil yang dihasilkan cenderung tidak sebagaimana mestinya. Apabila masalah ini dibiarkan terus berlangsung, maka dikhawatirkan guru salah melakukan diagnosis keberhasilan belajar siswa, yang pada sisi negatif berdampak pada demotivasi belajar siswa.

Bertolak dari permasalahan tersebut, maka sangatlah strategis apabila dikembangkan sebuah produk yang menjadi solusi bagi masalah yang terjadi. Supaya produk yang dikembangkan dapat dipertanggung jawabkan secara ilmiah, maka pengembangan perlu dilakukan melalui penelitian. Produk yang dikembangkan dalam penelitian ini adalah Computer Based Evaluation Essay Model (CBEEM). Produk ini adalah perangkat lunak tes berbasis komputer (computer based test) yang khusus dikembangkan untuk soal uraian. Perangkat lunak memiliki kemampuan untuk melakukan koreksi jawaban siswa dengan metode yang dapat dipertanggung jawabkan, sehingga dapat mengatasi masalah-masalah koreksi jawaban secara manual seperti telah dikemukakan sebelumnya. Dengan demikian, tujuan dari penelitian ini adalah mengembangakan perangkat Computer Based Evaluation Essay Model (CBEEM).

\section{METODE}

Penelitian ini adalah penelitian pengembangan (Research and Development). Produk yang dikembangkan adalah perangkat lunak yang diberi nama Computer Based Evaluation Essay Model (CBEEM). Model pengembangan yang digunakan dalam penelitian ini adalah model Plomp (2013), di mana langkah pengembangan yang dilakukan terdiri dari Preliminary research, Development/prototype phase, dan Assessment phase. Setiap tahap pengembangan tersebut dijelaskan sebagai berikut.

1. Pada tahap preliminary research, data berbentuk data kualitatif yang dikumpulkan melalui wawancara kepada 10 orang guru yang terdiri dari guru dari jenjang SD, SMP, dan SMA. Data divalidasi dengan teknik triangulasi sumber untuk selanjutnya dianalisis dengan teknik Miles and Hubberman (2014). Kegiatan ini dilakukan sepanjang bulan Juli hingga Agustus 2020. Hasil yang diperoleh dari tahap penelitian ini akan dibandingkan dengan teori-teori yang ada, utamanya teori tentang kesalahan koreksi sebagaimana ditulis oleh Rukajat (2018).

2. Masalah-masalah dan kendala-kendala yang menjadi temuan dari tahap preliminary research kemudian menjadi basis pengembangan (development/prototype phase). Pengembangan dilakukan pada bulan September 2020 dengan basis pemrograman menggunakan Visual Basic untuk selanjutnya di-online-kan. Prototype CBEEM diarahkan supaya dapat mengatasi 
masalah dan kendala dalam proses koreksi jawaban essay siswa secara manual.

3. Pada tahap assessment phase, prototype CBEEM dievaluasi oleh ahli dan praktisi. Pada penelitian ini, terdapat 2 orang ahli dan 2 orang praktisi (guru) yang menjadi validator. Evaluasi dilakukan dengan menggunakan instrumen angket berisikan pertanyaan tertutup dalam skala likert 1-5 berikut masukan secara kualitatif. Hasil isian angket secara kualitatif, menjadi bahan bagi revisi CBEEM. Tahap ini dilakukan pada bulan November 2020.

Setelah melalui ketiga proses pengembangan dalam model Plomp tersebut, diharapkan CBEEM dapat berlanjut ke tahapan selanjutnya, yaitu diseminasi, komersialisasi, maupun pengembangan pada tahap lebih lanjut.

\section{HASIL DAN PEMBAHASAN Hasil Penelitian}

Pengembangan CBEEM telah dilakukan dan menghasilkan prototype yang siap didiseminasikan, dikomersialisasi, dan dikembangkan lebih lanjut. Pengembangan dilakukan sesuai rancangan yang telah direncanakan, yaitu melalui 3 tahap pengembangan dari Plomp, yaitu tahap penelitian, tahap pengembangan, dan tahap evaluasi. Bagian pertama di bab ini akan memaparkan proses pengembangan yang berisikan 3 kegiatan yang telah dilakukan berikut hasil dari setiap kegiatannya. Selanjutnya bagian kedua akan memaparkan produk final yang telah dihasilkan dari rangkaian penelitian pengembangan ini.

\section{Proses Pengembangan}

Sebagaimana

telah dirancang sebelumnya, pengembangan dilakukan dengan mengikuti 3 langkah pengembangan sebagaimana dikemukakan oleh Plomp. Ketiga langkah tersebut adalah tahap penelitian, tahap pengembangan, dan tahap evaluasi. Berikut akan dijelaskan kegiatan-kegiatan yang dilakukan pada ketiga tahapan tersebut.

\section{Tahap Penelitian}

Sepuluh guru yang menjadi responden dalam penelitian ini telah memberikan data mengenai kesulitan-kesulitan yang dihadapi ketika melakukan koreksi terhadap jawaban siswa untuk soal uraian. Kesulitan-kesulitan yang disampaikan oleh satu guru cenderung juga disampaikan oleh guru-guru yang lainnya, sehingga dapat dikatakan data telah terkonfirmasi dan lolos dalam proses triangulasi. Data yang ditemukan juga cenderung sama dengan teori-teori mengenai kesalahan guru dalam melakukan koreksi soal uraian.

2. Tahap Pengembangan

Hasil dari tahap penelitian menjadi dasar untuk tahap pengembangan produk. Produk dikembangkan berdasarkan evaluasi secara otomatis seperti pernah dikembangkan sebelumnya untuk metode pembelajaran (Santosa \& Togatorop, 2017). Pengembangan dilakukan dengan cara penyusunan algoritma kerja dan konsep software oleh peneliti. Konsep ini dirancang supaya mampu mengatasi permasalahan yang ditemukan di tahap penelitian. Pada mulanya model yang dikembangkan hanya spesifik untuk 1 mata pelajaran saja. Namun berdasarkan masukan dari guru-guru yang lain, maka software dirancang supaya dapat digunakan oleh mata pelajaran yang lain. Untuk itu, software hanya berisikan kerangka kerja yang perlu diisi sendiri oleh guru masing-masing. Dengan demikian, maka software dapat digunakan pada mata pelajaran apapun. Setelah konsep selesai disusun, programer mulai mengerjakan pengembangan software ini dengan pengawasan langsung dari peneliti.

\section{Tahap Evaluasi}

Setelah software selesai dikembangkan, software dievaluasi melalui validasi dari ahli dan praktisi. Terdapat 2 orang ahli dan 2 orang praktisi (guru) yang menjadi validator. Adapun angket yang diisi terdiri dari 5 item pernyataan, yaitu karakteristik software dalam hal simpel, applicable, user friendly, solving oriented, dan innovative. Rata-rata skor yang diperoleh dari semua item pada semua validator adalah 4,5. Selain itu, secara kualitatif, validator menyatakan bahwa model ini dapat mengatasi masalah koreksi jawaban soal uraian yang menjadi momok bagi guru, sehingga model ini layak untuk digunakan.

Tabel 1. Hasil Validasi Produk Kriteria Validator Validator 2

\begin{tabular}{lcc} 
& $\mathbf{1}$ & \\
\hline Simple & 4 & 4 \\
\hline Applicable & 5 & 5 \\
\hline User Friendly & 4 & 4 \\
\hline Solving Oriented & 5 & 5 \\
\hline Innovation & 4 & 5 \\
\hline Rata-rata & 4,4 & 4,6 \\
\hline
\end{tabular}


Berdasarkan tabel 1 di atas, tampak bahwa ratarata nilai validasi dari kedua validator adalah 4,5. Selain itu, terdapat komentar dari validator, di mana produk ini menjadi solusi untuk koreksi jawaban soal uraian, walaupun akan sulit digunakan oleh guru-guru yang kurang baik dalam hal literasi teknologi.

\section{Hasil Pengembangan}

Model yang dikembangkan terbukti mampu menjawab kebutuhan dan merupakan perbaikan dalam rangka mengeliminasi kekurangan model yang sudah ada (model faktual) yang diperoleh melalui tahap preliminary research. Dengan adanya bantuan dari komputer, diharapkan soal tes uraian lebih mudah dikembangkan, memiliki sistem koreksi yang lebih baik, dan memudahkan siswa untuk menuangkan pemikirannya. Oleh karena itu, CBEEM (Computer Based Essay Evaluation Model) perlu dirinci kedalam tiga bagian berdasarkan tugas dan tujuan menjawab permasalahan. Ketiga bagian tersebut adalah penyusunan pengantar instrumen, penyusunan soal uraian, pengembangan sistem koreksi jawaban.

1. Pengatar Instrumen

Pengantar instrumen terdiri dari judul instrumen, perintah atau petunjuk mengerjakan, dan lamanya waktu yang diberikan kepada siswa untuk mengerjakan soal. Dalam hal ini, guru dapat mengisi dalam kolom-kolom yang disediakan dalam C-BEEM. Waktu yang diberikan kepada siswa menjadi patokan CBEEM untuk membatasi siswa. Apabila waktu yang diberikan sudah habis, maka semua jawaban siswa yang belum disubmit secara otomatis akan disubmit oleh program. Secara teknis, pengisian pengantar instrumen ini dapat diisikan pada kotak-kotak yang ada pada gambar 1.

Apabila guru telah selesai mengisi isian pengantar instrumen, maka guru dapat klik pada submit dan tampilan C-BEEM akan berubah menjadi tampilan dasar untuk guru dapat menyusun soal. Meski demikian, apabila guru merasa perlu mengubah beberapa isian dalam pengantar, guru dapat langsung klik pada edit.

2. Penyusunan Soal Uraian

Tahap penyusunan soal pada model faktual tampak hampir tidak memiliki kelemahan. Guru menuliskan soal secara singkat, padat dan jelas mengenai definisi, klasifikasi, maupun ciri-ciri dari objek yang ditanyakan. Permasalahan yang terjadi pada tahap ini justru pada bobot nilai dari soal yang disusun. Dengan tingkat kesulitan yang berbeda, dan adanya perbedaan panjang jawaban standar, tentu bobot soal tertentu tidak dapat disamakan dengan soal yang lain. Contohnya, ketika guru membuat 5 soal, bobot setiap soal tidak harus merata sebesar 20, namun dapat berbeda-beda, misalnya 30, 10, 20, 25 dan 15 (total bobot semua soal bila dijumlahkan harus sama dengan 100).

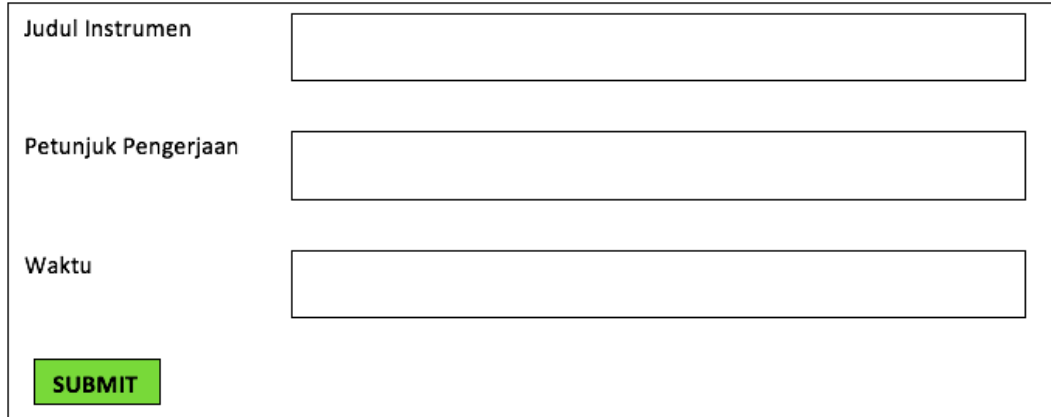

Gambar 1. Tampilan Isian Pengantar Instrumen 


\section{TES AKHIR SEMESTER PENGANTAR ILMU EKONOMI EDIT}

Jawablah Pertanyaan-Pertanyaan Berikut dengan Benar! EDIT

Waktu: 60 Menit EDIT

(Belum ada Soal yang dibuat)

\section{BUAT SOAL}

TOTAL

0

Gambar 2. Contoh Tampilan Setelah Pengantar Instrumen Diisi Oleh Guru

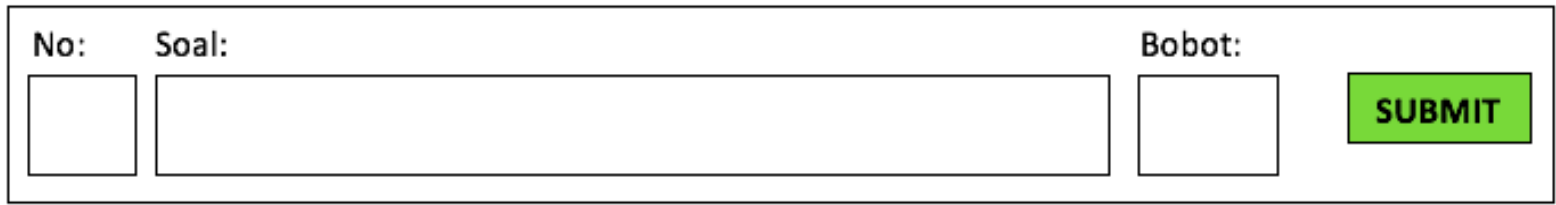

Gambar 3. Tampilan Pengisian Soal Dalam C-BEEM

Oleh karena itu, pada sesi ini C-BEEM harus menyediakan minimal 3 tempat, yaitu tempat untuk nomer soal, tempat untuk mengisikan soal yang ditanyakan, dan tempat untuk bobot soal. Guna sampai pada halaman ini, guru harus klik link buat soal pada tampilan dasar C-BEEM.

Apabila guru telah menginput semua soal, maka secara otomatis C-BEEM harus menghitung jumlah keseluruhan bobot soal, dan menampilkannya dalam bentuk ringkas. C-
BEEM juga harus memberikan kesempatan bagi guru untuk mengubah soal dan bobotnya maupun menambahkan soal. Selain itu, CBEEM juga akan memberikan warning apabila jumlah bobot tidak mencapai 100 (kurang atau lebih dari 100), sehingga guru harus merevisi bobot soalnya. Apabila hal tersebut sudah tepat, maka link submit akan terbuka, dan guru dapat mengakhiri dengan klik submit (seperti gambar berikut) setelah menginput kunci jawaban.

\section{TES AKHIR SEMESTER PENGANTAR ILMU EKONOMI EDIT}

Jawablah Pertanyaan-Pertanyaan Berikut dengan Benar! EDIT

Waktu: 60 Menit EDIT

1. Sebutkan definisi Ilmu Ekonomi menurut Samuelson!

2. Sebutkan dua prinsip utama dalam kegiatan ekonomi!

3. Jelaskan pengertian produksi!

4. Apa yang dimaksud dengan optimasi dalam produksi?

5. Tuliskan hukum ekonomi pada sisi konsumsi!

Gambar 4. Tampilan Setelah 5 Soal Diinput Oleh Guru 


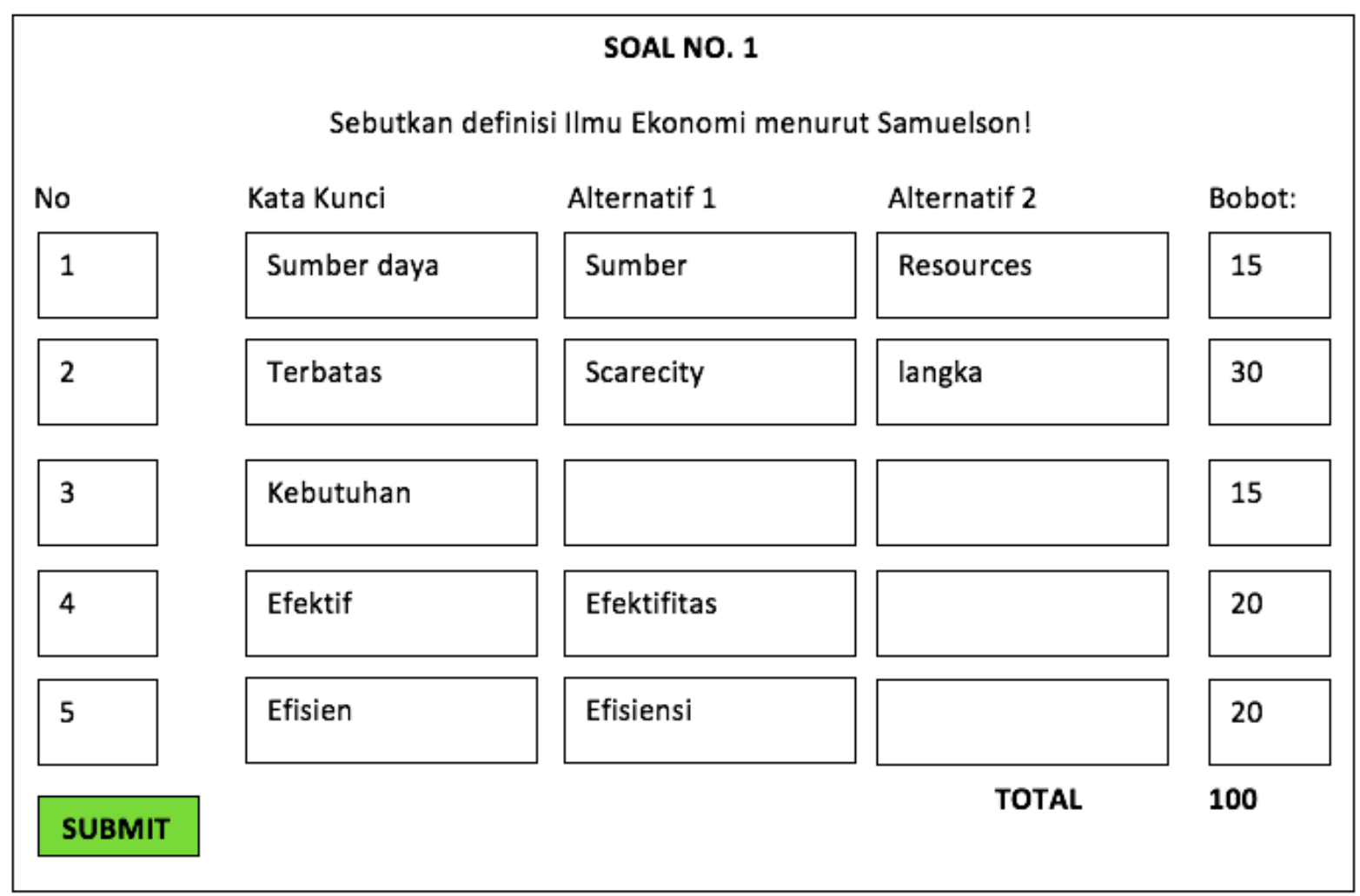

Gambar 5. Tampilan Pengisian Kata Kunci dan Bobot

\begin{tabular}{|c|c|c|c|c|}
\hline Soal No. 1 & Jawaban Siswa "A" & Kata Kunci & Bobot & Nilai \\
\hline \multirow{5}{*}{$\begin{array}{c}\text { Sebutkan definisi } \\
\text { Ilmu Ekonomi } \\
\text { menurut Samuelson! }\end{array}$} & \multirow{5}{*}{$\begin{array}{l}\text { Ilmu Ekonomi adalah Ilmu } \\
\text { yang mempelajari } \\
\text { bagaimana manusia } \\
\text { memanfaatkan sumber daya } \\
\text { yang terbatas mtuk } \\
\text { memenuhi kebutuhan yang } \\
\text { tidak terbatas. }\end{array}$} & $\begin{array}{l}\text { Sumber daya, Sumber, } \\
\text { Resources }\end{array}$ & 15 & 15 \\
\hline & & $\begin{array}{l}\text { Terbatas, Scarecity, } \\
\text { Langka }\end{array}$ & 30 & 30 \\
\hline & & Kebutuhan & 15 & 15 \\
\hline & & Efektif, Efektifitas & 20 & 0 \\
\hline & & Efisien,Efisiensi & 20 & 0 \\
\hline & Nilai Soal No. 1 & & & 60 \\
\hline
\end{tabular}

Gambar 6. Contoh Perhitungan Nilai Siswa Pada Satu Soal

3. Pengembangan Sistem Koreksi Jawaban

Berdasarkan model faktual yang diperoleh, tampak bahwa guru mengoreksi jawaban siswa dengan cara mencocokan katakata kunci yang ada dalam jawaban dengan kata kunci yang menurut guru seharusnya ada dalam jawaban. Oleh karena itu, setiap soal harus dilengkapi dengan kata-kata kunci sebagai acuan bagi C-BEEM untuk mengoreksi jawaban siswa. Sering kali, beberapa kata kunci memiliki bobot yang berbeda-beda. Dengan demikian, selain menginput kata-kata kunci, guru juga harus menginput bobot setiap kata kunci maupun alternatif kata kunci lain yang mungkin akan ditulis oleh siswa. Misalnya, kata kelangkaan dapat diganti dengan keterbatasan, atau cukup dengan kata dasarnya, yaitu langka, terbatas, dll. Dalam hal bobot, setiap kata kunci dimungkinkan memiliki bobot masing-masing, di mana jumlah seluruh bobot dari kata kunci yang disediakan harus 100 . 
Secara teknis, setelah guru klik pada link input kunci, C-BEEM akan mengarahkan guru untuk menginput kata-kata kunci jawaban dan bobotnya. Apabila semua kata kunci telah diinput, C-BEEM akan menghitung jumlah bobot, dan menampilkan link submit bila jumlah bobot sudah mencapai 100. Dalam hal ini, CBEEM menyediakan tempat bagi 5 kata kunci yang dilengkapi dengan 2 alternatif kata kunci untuk setiap tempatnya.

Sama dengan penyusunan soal di awal, C-BEEM tidak akan menunjukkan link submit kata kunci apabila total bobot dari kesemua kata kunci tidak mencapai 100 (kurang dari atau lebih dari 100). Dengan klik submit, maka guru telah selesai menginput kata kunci. Kedepannya, kata kunci dapat diedit oleh guru dengan klik lagi pada input kata kunci pada halaman utama CBEEM. Untuk dapat menyelesaikan pengembangan soal ini, guru harus menginput semua kata kunci dari semua soal.

Proses koreksi yang akan dilakukan adalah mencocokkan jawaban siswa setiap nomornya dengan kata kunci yang telah diinput oleh guru. Apabila jawaban siswa mengandung satu kata yang sama dengan kata kunci, maka siswa akan mendapatkan nilai sesuai bobot kata kunci. Nilai yang diperoleh siswa bergantung pada banyaknya kata kunci yang muncul pada jawaban siswa. Berikut simulasi perhitungan nilai siswa pada nomor 1 .

Pada contoh di atas, tampak bahwa jawaban siswa menyinggung 3 kata kunci yang disediakan guru, yaitu sumber daya, terbatas, dan kebutuhan. Berdasarkan bobotnya, ketiga kata kunci tersebut memiliki bobot 15, 30, dan 15, sehingga nilai yang diperoleh siswa pada nomor 1 ini adalah $15+30+15=60$. Sistem koreksi yang sama juga berlaku untuk nomornomor yang lain.

Nilai akhir siswa akan langsung muncul setelah siswa selesai mengerjakan soal. Nilai akhir diperoleh dari jumlah semua nilai pada setiap nomor setelah diperhitungkan dengan bobot soalnya. Misalnya siswa "A" mendapatkan nilai untuk soal nomor 1 hingga 5 secara berurutan adalah 60, 100, 70, 80, dan 50 . Sedangkan bobot setiap soal adalah 30, 10, 20, 20 , dan 20. Nilai akhir yang didapat siswa adalah nilai pada nomor tersebut dikali dengan bobot, dan dibagi dengan 10. Sehingga nilai akhirnya 68. Gambar berikut merupakan contoh pada salah satu siswa.

\section{Pembahasan Hasil Penelitian}

Soal tes uraian memiliki beberapa keunggulan dibandingkan dengan bentuk-bentuk soal tes yang lain. Menurut Aslamiah (2020), soal tes uraian mampu untuk menilai ranah kognitif siswa pada tingkat pemikiran yang tinggi (High Order Thinking Skill). Selain itu, penelitian dari Sari (2018) menunjukkan bahwa tes uraian juga mampu mengukur kemampuan berpikir kritis. Meski demikian, keunggulan tersebut akan menjadi percuma apabila guru tidak mengoreksi jawaban secara tepat. Untuk itu maka para ahli berupaya mengembangkan berbagai strategi maupun produk untuk dapat mengatasi masalah kesalahan dalam koreksi soal tes uraian, misalnya Partial Credit Model (PCM) yang diteliti oleh Purwati dan Sumandya (2019). Model yang digunakan oleh Purwanti dan Sumandya ini berbeda dengan CBEEM.

\begin{tabular}{|c|c|c|c|}
\hline No Soal & Nilai & Bobot & Hasil Akhir \\
\hline 1 & 60 & 30 & 18 \\
\hline 2 & 100 & 10 & 10 \\
\hline 3 & 70 & 20 & 14 \\
\hline 4 & 80 & 20 & 16 \\
\hline 5 & 50 & 20 & $\mathbf{6 8}$ \\
\hline
\end{tabular}

Gambar 7. Contoh Nilai Akhir yang Diperoleh Siswa "A" 
LEMBAR JAWAB SOAL NO. 1

Sebutkan definisi Ilmu Ekonomi menurut Samuelson!

Jawaban:

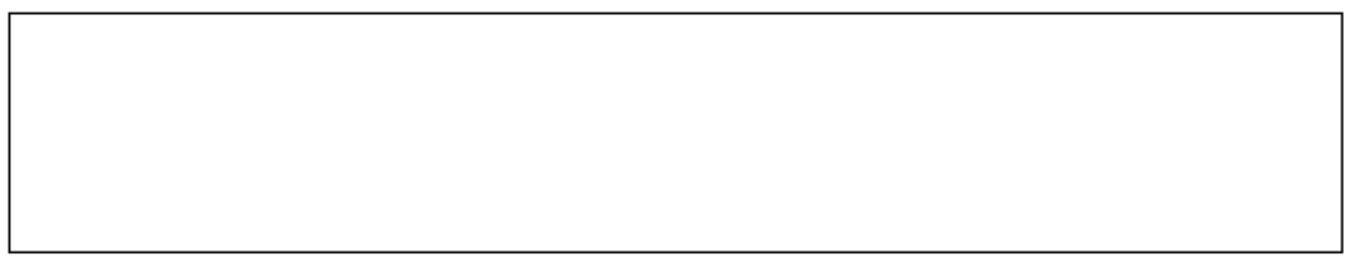

Waktu untuk menjawab soal ini: 18 menit

Waktu tersisa untuk soal ini: $16^{\prime} 20^{\prime \prime}$

Waktu tersisa untuk menjawab semua soal: $58^{\prime} 20^{\prime \prime}$

Gambar 8. Tampilan Lembar Jawab Siswa yang Dilengkapi Dengan Pengingat Waktu

Model faktual strategi menjawab siswa memuat berbagai kelemahan yang sebenarnya merupakan akibat dari menulis tangan. Dengan adanya CBEEM, siswa tidak perlu lagi menulis menggunakan pulpen, namun dengan cara mengetik. Terdapat beberapa keunggulan mengetik jika dibandingkan dengan menulis tangan:

- Mengurangi perasaan stres dan tertekan. Menurut Anam dan Jauhari (2020), seseorang yang menulis dengan cara mengetik memiliki tingkat stres yang lebih rendah dibandingkan dengan menulis tangan. Dengan rendahnya tingkat stres ini,

- Kelelahan yang timbul akibat akibat mengetik tidak tinggi kelelahan tangan akibat menulis tangan. Dengan demikian, siswa dapat menuangkan lebih banyak ide yang dimiliki dalam pikirannya.

- Siswa dapat dengan mudah menghapus jawaban apabila dirasa salah, dan menggantinya dengan jawaban yang baru. Tulisan tangan hanya dapat dihapus dengan tip-ex atau penghapus (bila menggunakan pensil) yang membutuhkan tenaga ekstra, serta waktu yang lama.
- Siswa mudah mengorganisasikan jawaban sesuai pikirannya. Apabila siswa merasa jawaban kurang sistematis, siswa dapat menyisipkan jawaban di antara kata atau kalimat dengan leluasa. Kalimat yang ditulis dengan tulisan tangan akan sulit disisipi kalimat atau kata lain. Kalaupun disisipi, siswa perlu menghapus kalimat yang di belakangnya (cukup menghabiskan waktu dan tenaga).

- Dari segi waktu, pada umumnya menulis tangan membutuhkan waktu yang lebih lama dibandingkan dengan mengetik. Oleh karena itu, dengan adanya C-BEEM, siswa memiliki waktu lebih untuk dapat berpikir dan mengorganisasikan sajian pemikirannya.

Berdasarkan penjelasan-penjelasan tersebut, tampak bahwa C-BEEM telah dapat mengatasi permasalahan-permasalahan siswa ketika mengerjakan soal tes uraian dengan cara menulis tangan. Meski demikian, supaya lebih optimal dalam hal waktu, C-BEEM akan dilengkapi dengan pengingat waktu, supaya siswa dapat memperhitungkan waktu yang digunakan untuk menjawab setiap pertanyaan maupun menjawab keseluruhan soal yang ada dalam tes. 


\begin{tabular}{|c|c|c|}
\hline No Soal & Bobot & Waktu Untuk Mengerjakan \\
\hline 1 & 30 & 18 Menit \\
\hline 2 & 10 & 6 Menit \\
\hline 3 & 20 & 12 Menit \\
\hline 4 & 20 & 12 Menit \\
\hline $5 \quad 20$ & 12 Menit \\
\hline \multicolumn{2}{|c|}{ Total Waktu } & $\mathbf{6 0}$ Menit \\
\hline
\end{tabular}

Gambar 9. Contoh Agihan Waktu Untuk Mengerjakan Setiap Soal

Pengingat waktu akan diwujudkan dalam bentuk angka yang ada dalam lembar jawab siswa. Waktu yang ditampilkan mencakup waktu untuk mengerjakan semua soal (waktu keseluruhan), dan waktu untuk mengerjakan soal yang sedang dikerjakan. Hal ini dilakukan supaya waktu yang dimiliki mahasiswa tidak habis untuk mengerjakan soal-soal tertentu saja.

Pengingat waktu untuk setiap soal hanya berperan sebagai pengingat, dan tidak membatasi siswa jika ingin menghabiskan waktu lebih untuk mengerjakan soal tersebut. Dengan demikian, walau waktu yang disediakan untuk menjawab satu soal telah habis, namun waktu untuk menjawab keseluruhan masih tersedia, maka siswa dapat terus mengerjakan soal yang sedang dikerjakannya. Sistem baru berhenti ketika waktu untuk menjawab semua soal sudah habis.

Terkait pengalokasian waktu untuk menjawab setiap soal, C-BEEM akan menyediakan waktu berdasarkan bobot soal yang telah ditetapkan oleh guru. Semakin tinggi bobot, maka waktu yang tersedia semakin lama dan sebaliknya. Hal ini diperhitungkan secara proporsional.

Apabila sebuah soal dikerjakan melebihi batas waktu yang ditentukan, maka agihan waktu untuk soal-soal selanjutnya juga akan berkurang secara proporsional. Hal ini diharapkan dapat membantu siswa untuk mengembangkan manajemen waktu yang lebih baik. Meski demikian, perangkat manajemen waktu dalam pengerjaan soal dimungkinkan dapat berdampak pada kecemasan siswa dalam mengerjakan soal tes (Minarto, 2018). Untuk itu maka perlu adanya studi lebih lanjut dan mendalam mengenai kecemasan siswa dalam mengerjakan tes.

\section{PENUTUP}

Berdasarkan pengembangan yang telah dilakukan, disimpulkan bahwa Computer Based Evaluation Essay Model (CBEEM) yang terdiri dari tahap penyusunan instrumen oleh guru, pengerjaan soal oleh siswa, dan proses koreksi oleh software efektif untuk digunakan dan mampu mengatasi permasalahan-permasalahan koreksi yang dihadapi oleh guru. Untuk itu disarankan kepada guru untuk menggunakan software ini apabila hendak mengevaluasi hasil belajar siswa dengan soal uraian. Selain itu, perlu dilakukan penelitian lanjutan mengenai efektifitas software setelah digunakan. Penelitian dapat berbentuk penelitian eksperimen.

\section{UCAPAN TERIMAKASIH}

Artikel publikasi ini merupakan luaran dari hibah penelitian yang diterima oleh peneliti. Oleh karena itu, peneliti mengucapkan terimakasih disampaikan kepada Direktorat Riset dan Pengabdian kepada Masyarakat (DRPM) Kementerian Riset dan Teknologi, Badan Riset dan Inovasi Nasional (Kemristek BRIN) yang telah memberikan pendanaan bagi penelitian ini untuk skema hibah penelitian PDP. Selain itu, terimakasih juga disampaikan kepada Lembaga Riset dan Pengabdian kepada Masyarakat (LRPM) President University yang telah memberikan support untuk diperolehnya hibah penelitian ini. Serta kepada guru-guru dan validator yang menjadi objek penelitian dihaturkan terimakasih yang sebesar-besarnya.

\section{DAFTAR PUSTAKA}

Anam, K., Jauhari, H. (2020). Keyboarding Skill. Cara Praktis Terampil Mengetik 10 Jari. Batu: Literasi Nusantara. 
Aslamiah, N. (2020). Pengembangan Instrumen Evaluasi Bentuk Tes Uraian Berbasis Higher Order Thinking Skills (HOTS) Pada Mata Pelajaran Akidah Akhlak Di Mts Negeri 1 Pandeglang. Repository UIN Banten

Miles, M. B., Huberman, A. M., Saldana, J. (2014). Qualitative Data Analysis, A. Methods Sourcebook, Edition 3. Sage Publications.

Minarto, W. Y. (2018). Hubungan Kesiapan Belajar, Manajemen Waktu, Kecemasan Dalam Mengerjakan Tes, dan Hasil Belajar Mata Pelajaran Teknik Listrik Dasar Otomotif Siswa SMK. Teknologi dan Kejuruan. Jurnal Teknologi, Kejuruan, dan Pengajarannya. Vol. 41 (1).

Plomp, T., (2013). Introduction to Educational Design Research. Enschede, the Netherlands: SLO.
Purwanti, N. K. R., Sumandya, I. W. (2019). Penerapan Partial Credit Model (PCM) dalam Mengevaluasi Tes Uraian. Emasains: Jurnal Edukasi Matematika dan Sains. Vol. 8 (1).

Rukajat, A., (2018). Teknik Evaluasi Pembelajaran. Sleman: Deepublish.

Santosa, D. S. S, Togatorop, M, (2017). Evaluasi Metodologis Pembelajaran Berbasis Penelitian. Prosiding Seminar Pendidikan Ekonomi dan Bisnis. 3 (1).

Sari, D. W. (2018). Pengembangan Instrumen Tes Uraian Berbasis Pendekatan Saintifik Untuk Mengukur Kemampuan Berpikir Kritis Peserta Didik Kelas V SD. Digital Repository Unila.

Stufflebeam, L. D., Coryn, C. L. S, (2014). Evaluation Theory, Models, and Applications. San Francisco: Jossey-Bass. 